\title{
Genetic variability assessment in the genus Passiflora by SSR markers
}

\author{
Claudia Lougon Paiva ${ }^{1 *}$, Alexandre Pio Viana ${ }^{1}$, Eileen Azevedo Santos ${ }^{1}$, \\ Jôsie Cloviane de Oliveira Freitas ${ }^{1}$, Raimundo Nonato Oliveira Silva ${ }^{1}$, and Eder Jorge de Oliveira ${ }^{2}$
}

\begin{abstract}
The genus Passiflora encompasses many species that are endemic to the Brazilian territory, including some with economic value. Studies on genetic diversity in this genus are fundamental because they allow understanding genetic variability and distance. The present study aimed to determine the genetic variability and distances among 10 species of the genus Passiflora by using microsatellite markers (Simple Sequence Repeat, SSR). Twenty-eight heterologous microsatellite markers were tested, but only 12 were used in the diversity analysis because they amplified in at least $80 \%$ of the species. A clear separation was observed among the subgenuses studied, as well as wide variation among the accessions of Passiflora. This knowledge enables breeders to explore diversity and transfer favorable alleles found in wild species.
\end{abstract}

Key words: Breeding, genetic diversity, Passiflora.

\section{INTRODUCTION}

The genus Passiflora groups species are known as passion fruit. It comprises about 530 species, of which approximately 140 have diversified in the Brazilian territory. Eighty-two are endemic to Brazil, which makes the country a center of genetic diversity of the genus (Bernacci et al., 2013). The diversity of wild passion fruit species in Brazil is a potential to be explored and a promising research field in various aspects of plant breeding.

The wild species of Passiflora have characteristics of interest to passion fruit culture, including longevity, adaptation to adverse weather conditions, extended flowering period, higher concentration of chemicals of interest to pharmaceutical and cosmetic industries and resistance to diseases (Meletti, 2011). The latter is one of the main goals of passion fruit breeding programs (Junqueira et al., 2006). In spite of the importance of this crop and the huge number of species found in Brazil, there is still little knowledge about diversity in this genus, compared to other species. Genetic variability measurement is a fundamental activity for plant breeding and conservation of many species.

${ }^{1}$ Universidade Estadual do Norte Fluminense Darcy Ribeiro/UENF, Laboratório de Melhoramento Genético Vegetal/LMGV, Av. Alberto Lamego, s/n, Campos dos Goytacazes, Rio de Janeiro, Brasil. *Corresponding author (claudialougon@gmail.com).

${ }^{2}$ Embrapa Mandioca e Fruticultura, Rua Embrapa $s / n^{\circ}$, Cruz das Almas, Bahia, Brasil.

Received: 20 December 2013.

Accepted: 24 May 2014.

doi:10.4067/S0718-58392014000300015
Among other alternatives, it can be performed through morphological characterization, in which inheritable traits are observed, measured, and documented (Vicente et al., 2005). However, since the number of descriptors is small and some traits are affected by environmental changes, morphological characterization has been limited to germplasm documentation and registration of cultivars. Therefore, DNA molecular markers have contributed to estimate variability, since they can detect significant differences at DNA level. Molecular markers can perform characterization with greater precision and in large scale (Varshney et al., 2005).

Microsatellites stand out among molecular markers in the analysis of genetic diversity because they are codominant, multi-allelic, polymorphic, and reproducible. Thus, highly informative content can be generated (Schlötterer, 2004). Comparative studies on Passiflora have been very successful when using Randomly Amplified Polymorphic (RAPD) molecular markers (Viana et al., 2003; Pérez et al., 2007; Viana et al., 2010), inter-simple sequence repeat (ISSR) (Santos et al., 2011), and chloroplast genes (Yockteng and Nadot, 2004). However, there are only a few studies on the use of microsatellite markers for the characterization of Passiflora involving several species. Microsatellite markers have been developed for some species of the genus Passiflora, and for P. edulis Sims (Oliveira et al., 2005), P. alata Curtis (Pádua et al., 2005), P. cincinnata Mast. (Cerqueira-Silva et al., 2012), and P. contracta Vitta (Cazé et al., 2012). However, microsatellites have not been developed yet for most species of this genus. Thus, this study aimed to investigate the cross-amplification of microsatellite markers for 10 species of Passiflora and quantify the genetic variability among the genotypes. 


\section{MATERIAL AND METHODS}

\section{Germplasm and extraction of genomic DNA}

Fifty-five genotypes of Passiflora spp. comprising 10 species were evaluated. They were obtained from the germplasm collection of the Universidade Estadual do Norte Fluminense (UENF) and the Empresa Brasileira de Pesquisa Agronômica EMBRAPA (Brazilian Enterprise for Agricultural Research). The plants were germinated and grown in a greenhouse at the UENF research support unit (Table 1).

Young leaves were collected and stored at $-80{ }^{\circ} \mathrm{C}$ in an ultrafeezer. About $50 \mathrm{mg}$ macerated tissue were transferred to $2 \mathrm{~mL}$ tubes and immersed in liquid $\mathrm{N}_{2}$ for DNA extraction, in accordance with the protocol of Doyle and Doyle (1990), with modifications. The integrity of the extracted DNA was checked on $1 \%$ agarose gel and GelRed staining. A spectrophotometer (NanoDrop 2000c UV-Vis spectrophotometer, Thermo Scientific, Wilmington, Delaware, USA) was used for quantification, with absorbance read at $260 \mathrm{~nm}$ wavelength.

Optimization of the polymerase chain reaction (PCR) Primers developed for P. edulis (Oliveira et al., 2005) and $P$. alata (Pádua et al., 2005) were used to assess crossamplification in the species analyzed (Table 2). The primers that amplified in most species were used in the analysis of variability in the genus Passiflora. The PCR was performed with $10 \mathrm{ng}$ DNA, $0.5 \mu \mathrm{M}$ primers and 0.5 U Taq DNA Polymerase, $0.02 \mathrm{mM}$ dNTP, and $1.5 \mathrm{mM}$ magnesium chloride and PCR buffer (1X), with a final volume of $13 \mu \mathrm{L}$ per sample.

The amplifications were conducted in a thermal cycler (Veriti 384-Well Thermal Cycler, Applied Biosystems, Thermo Scientific). The amplification program consisted

Table 1. Accessions of Passiflora, its origin, and the number of plants used in the analysis of genetic diversity.

\begin{tabular}{lllc}
\hline Accession & \multicolumn{1}{c}{ Species } & \multicolumn{1}{c}{ Origin } & $\begin{array}{c}\text { Number } \\
\text { of plants }\end{array}$ \\
\hline BGP235 & Passiflora alata Curtis & Brasília & 3 \\
BGP016 & Passiflora cincinnata Mast. & Alagoas & 4 \\
BGP268 & P. cincinnata & Bahia & 3 \\
BGP274 & P. cincinnata & Bahia & 4 \\
BGP275 & P. cincinnata & Bahia & 3 \\
BGP290 & P. cincinnata & Bahia & 2 \\
BGP008 & Passiflora gibertii N.E. Br. & São Paulo & 2 \\
BGP198 & P. gibertii & Indisponível & 2 \\
UENF & P. gibertii & Rio de Janeiro & 3 \\
BGP237 & Passiflora setacea DC. & Bahia & 3 \\
BGP238 & P. setacea & Bahia & 3 \\
BGP272 & P. setacea & Bahia & 1 \\
UENF & P. setacea & Rio de Janeiro & 4 \\
UENF & P. setacea & Bahia & 2 \\
UENF & Passiflora mucronata Lam. & Bahia & 2 \\
São Francisco & P. mucronata & Rio de Janeiro & 2 \\
UENF & Passiflora micropetala & Rio de Janeiro & 1 \\
& Mart. ex Mast & & \\
UENF & Passiflora caerulea L. & Bahia & 1 \\
UENF & Passiflora suberosa L. & Rio de Janeiro & 4 \\
UENF & Passiflora coccinea Aubl. & Rio de Janeiro & 2 \\
UENF & Passiflora edulis Sims & Rio de Janeiro & 4 \\
\hline UENF: Univers & & \\
\hline
\end{tabular}

UENF: Universidade Estadual do Norte Fluminense.
Table 2. Identification of the loci used for genotyping $\mathbf{5 6}$ accessions of Passiflora.

\begin{tabular}{|c|c|c|c|}
\hline Locus & Starter "foward" & Starter "reverse" & Reference \\
\hline PE03 & gcagcgagggaagaaaaa & tgagacatcgtgcgtgaa & Oliveira, 2006 \\
\hline PE04 & atgcttttggaaatccgttt & tgctcatgcaaagtcactgg & Oliveira, 2006 \\
\hline PE08 & ccggatacccacgcatta & tctaatgagcggaggaaagc & Oliveira, 2006 \\
\hline PE11 & gcataagttgtcggtcttgg & cctcgaacctctatcatcca & Oliveira, 2006 \\
\hline PE12 & cgtaatattgtttgggcact & atcatgggcgaactcattt & Oliveira, 2006 \\
\hline PE13 & aagcaccccaatcgttga & cccectgecacetgagta & Oliveira, 2006 \\
\hline PE18 & ccgtgaaccaaccatttctc & ccgtgaaccaaccatttctc & Oliveira, 2006 \\
\hline PE20 & aggatcaccatagaaaaccat & gttaggttggcattgctctt & Oliveira, 2006 \\
\hline PE23 & caatccettgaccataga & cgtccatcettctcettt & Oliveira, 2006 \\
\hline PE24 & tcaaactgaactcgtaaagg & gtgctgggagactgatgtt & Oliveira, 2006 \\
\hline PE27 & ttgctcattgcactcatcct & gcagacatttcctggagca & Oliveira, 2006 \\
\hline PE35 & attatgcctaaaaаcccaaa & tgatccagaggttgagagg & Oliveira, 2006 \\
\hline PE37 & caaaaggataggcctgatgtc & tgcttggtcatccactgaag & Oliveira, 2006 \\
\hline PE38 & gatcggtcctcggttagac & agtcacacagcatgagaaatc & Oliveira, 2006 \\
\hline PE41 & atcggggttcgettatttg & cgttcatcctttagtgggcta & Oliveira, 2006 \\
\hline PE42 & gtcacttcattcttcctttcc & ttagcccactcaaacacaa & Oliveira, 2006 \\
\hline PE58 & gcaatttcaccatcttctget & gcaatttcaccatcttctgct & Oliveira, 2006 \\
\hline PE66 & ccatagtcccaacaagcatc & getgtggaccctaactcagtc & Oliveira, 2006 \\
\hline PE74 & ccctcttatcaatagcgttgg & gcacgagcacgagtatttatt & Oliveira, 2006 \\
\hline PE90 & tcaggaagattgcatgttagt & ctgggttttgtttatgttgc & Oliveira, 2006 \\
\hline A07FP1 & ggaagtgaaggagaagaaga & ccctctggttgtctacctac & Pádua et al., 2005 \\
\hline A08FP1 & cacatttgccgtcactgg & cggcatacgataaatctcctg & Pádua et al., 2005 \\
\hline A06FP1 & gggcggaagaaaagagaag & gaaacacacgatgcgaaaa & Pádua et al., 2005 \\
\hline A01FP3 & agagtcgtctaaccetcttgc & tcttgcttacgcgtggacta & Pádua et al., 2005 \\
\hline A01BP3 & gcgggattctcttgccttac & acaaaacacatcagccacca & Pádua et al., 2005 \\
\hline A08GP1 & taaccgacttcgcccaca & gagcaggggaagaaaaga & Pádua et al., 2005 \\
\hline A09DP1 & tggcaatttggtggttga & ccttaaccggcgttgga & Pádua et al., 2005 \\
\hline A03AP3 & gccttagcttgcaactttcg & ggaggcaacccgagtataaa & Pádua et al., 2005 \\
\hline
\end{tabular}

of the following steps: a cycle of 4 min at $94{ }^{\circ} \mathrm{C}$ for initial denaturation, 35 cycles of $1 \mathrm{~min}$ at $94{ }^{\circ} \mathrm{C}, 1 \mathrm{~min}$ at a specific temperature for each primer pair and $3 \mathrm{~min}$ at 72 ${ }^{\circ} \mathrm{C}$, and a cycle of $7 \mathrm{~min}$ at $72{ }^{\circ} \mathrm{C}$ for a final extension. The amplified fragments were then separated on $4 \%$ Metaphor agarose gel, stained with GelRed gel and subjected to UV light for visualization of the results (Fotodocumentador MiniBIS Pro, Bio-Imaging Systems, Jerusalem, Israel).

Twenty-eight primers were tested, with optimal annealing temperature for each primer ranging from 56 to $61{ }^{\circ} \mathrm{C}$. Separation of fragments was performed in high resolution Metaphor agarose gel. This strategy is effective for the analysis of simple sequence repeat (SSR) markers, since it is efficient, economical, easy to perform, and enables the separation of 20-800 bp alleles (Asif et al., 2008).

\section{Statistical analysis}

Genetic diversity was estimated by the number of alleles per polymorphic locus, observed heterozygosity (percentage of heterozygous individuals), and gene diversity (expected heterozygosity), which consists of the expected proportion of heterozygous individuals for the allelic frequencies observed and the polymorphic information content (PIC). The genetic distance was obtained by Shared Allele distance, which is based on the sharing of alleles among the genotypes assessed. The Unweighted Pair Group Method using Arithmetic Average (UPGMA) hierarchical method was used to group them. The Principal Coordinates Analysis was developed with the average distances for each species, which allowed the investigation of the distribution of the species of the genus 
Passiflora in the two-dimensional Cartesian plane. All values were obtained by using the Powermarker software system (Liu and Muse, 2005).

\section{RESULTS AND DISCUSSION}

\section{Transferability}

Out of the 28 microsatellite primers used, 12 were transferred to most species. The primers developed for $P$. edulis presented higher transferability rate, $P$. cincinnata was the species with the highest cross-amplification rate (80\%) while P. micropetala Mart. ex Mast presented the lowest (35\%). The low percentage of cross-amplification of these markers in P. micropetala may have resulted from the accumulation of molecular differences between $P$. edulis and P. micropetala. Out of the eight primers developed for $P$. alata, only two amplified in most species studied (A08FP1, A07FP1) (Table 3). The loci PE13, PE37, PE41, PE66, PE74, PE90, and A08FP1 were transferred to all the analyzed species (Table 4).

Twelve of the primers tested obtained a transferability rate equal to or higher than $80 \%$. Out of these, the primer A08FP1 amplified in all species (Table 4). Aiming to confirm the presence of hybrids in the cross between P. sublanceolata and P. foetida L., Santos et al. (2011) used the same primer, which was polymorphic for the parents, whose progeny presented bands belonging to

Table 3. Cross-amplification of 10 species of Passiflora using developed primers for Passiflora edulis and Passiflora alata.

\begin{tabular}{|c|c|c|c|c|c|c|c|c|c|c|}
\hline Loci & P.ed & P.al & P.se & P.mu & P.gi & P.ci & P.co & P.ca & P.su & P.mi \\
\hline PE03 & 1 & - & - & - & - & 1 & - & - & - & - \\
\hline PE04 & 1 & - & - & 1 & - & 1 & - & - & - & - \\
\hline PE08 & 1 & 1 & 1 & 1 & 1 & 1 & 1 & - & 1 & 1 \\
\hline PE11 & 1 & - & 1 & - & - & - & - & - & - & - \\
\hline PE12 & 1 & - & - & - & 1 & 1 & - & - & - & - \\
\hline PE13 & 1 & 1 & 1 & 1 & 1 & 1 & 1 & 1 & 1 & 1 \\
\hline PE18 & 1 & 1 & 1 & 1 & 1 & 1 & 1 & 1 & 1 & - \\
\hline PE20 & 1 & 1 & 1 & 1 & 1 & 1 & 1 & 1 & 1 & - \\
\hline PE23 & 1 & 1 & - & - & - & 1 & - & - & - & - \\
\hline PE24 & 1 & - & - & - & - & - & - & - & - & - \\
\hline PE27 & 1 & - & 1 & - & - & 1 & - & - & - & - \\
\hline PE35 & 1 & - & - & - & - & 1 & - & - & - & - \\
\hline PE37 & 1 & 1 & 1 & 1 & 1 & 1 & 1 & 1 & 1 & 1 \\
\hline PE38 & 1 & 1 & 1 & 1 & 1 & 1 & 1 & 1 & 1 & - \\
\hline PE41 & 1 & 1 & 1 & 1 & 1 & 1 & 1 & 1 & 1 & 1 \\
\hline PE42 & 1 & - & - & - & - & - & - & - & - & - \\
\hline PE58 & 1 & - & - & - & - & - & - & - & - & - \\
\hline PE66 & 1 & 1 & 1 & 1 & 1 & 1 & 1 & 1 & 1 & 1 \\
\hline PE74 & 1 & 1 & 1 & 1 & 1 & 1 & 1 & 1 & 1 & 1 \\
\hline PE90 & 1 & 1 & 1 & 1 & 1 & 1 & 1 & 1 & 1 & 1 \\
\hline $\mathrm{T}(\%)$ & 100 & 55 & 60 & 55 & 55 & 80 & 50 & 45 & 50 & 35 \\
\hline A07FP1 & - & 1 & 1 & 1 & 1 & 1 & 1 & 1 & 1 & - \\
\hline A08FP1 & 1 & 1 & 1 & 1 & 1 & 1 & 1 & 1 & 1 & 1 \\
\hline A06FP1 & - & 1 & - & - & - & - & - & - & - & - \\
\hline A01FP3 & - & - & - & - & - & - & - & - & - & - \\
\hline A01BP3 & - & - & - & - & - & - & - & - & - & - \\
\hline A08GP1 & - & 1 & 1 & - & - & - & - & - & - & - \\
\hline A09DP1 & - & 1 & - & - & - & - & - & - & - & - \\
\hline A03AP3 & - & 1 & - & - & - & - & - & - & - & - \\
\hline $\mathrm{T}, \%$ & 12.5 & 75 & 37.5 & 25 & 25 & 25 & 25 & 25 & 25 & 12.5 \\
\hline
\end{tabular}

T: rate of transferability; 1: observed amplification; -: without amplification. P.ed: Passifora edulis, P.al: Passiflora alata, P.se: Passiflora setacea, P.mu: Passiflora mucronata, P.gi: Passiflora gibertii, P.ci: Passiflora cincinnata, P.co: Passiflora coccinea, P.ca: Passiflora caerulea, P.su: Passiflora suberosa, P.mi: Passiflora micropetala.
Table 4. Transferability rate observed for microsatellite loci.

\begin{tabular}{lc}
\hline Locus & Transferability (\%) \\
\hline PE13, PE37, PE41, PE66, PE74, PE90, A08FP1 & 100 \\
PE08, PE18, PE20, PE38 & 90 \\
A07FP1 & 80 \\
PE04, PE12, PE23, PE27, PE35 & 30 \\
PE03, PE11, A08GP1 & 20 \\
PE24, PE42, PE58, A06FP1, A09DP1, A03AP3 & 10 \\
\hline
\end{tabular}

both parents. This indicates that the primer in question is highly polymorphic and can be used in studies with species on the genus Passiflora. Genetic variability quantification could be performed, since it was possible to achieve the transferability of 12 microsatellites for the species studied.

\section{Genetic diversity}

A low number of alleles was observed for all loci, ranging from 2 (PE37 and PE38) to 5 (PE66), and mean of 3.42. A total of 41 alleles were obtained for the 12 loci analyzed. Similar allelic variation was found by Cazé et al. (2012) when they were characterizing SSR loci developed for $P$. contracta in which the number of alleles per locus ranged from 2 to 9, with a mean equal to 5. Cerqueira-Silva et al. (2012) also found few alleles per locus, from 2 to 9 alleles. Oliveira et al. (2005) obtained up to 20 alleles at one locus and an average of 5.3 alleles per locus in a sample of 43 individuals. This shows that a low number of alleles per locus and few polymorphic microsatellite markers have been characteristic of the genus (Cerqueira-Silva et al., 2012). It may suggest that these loci concentrate in preserved regions, with low mutation rate.

The locus PE66 presented a greater number of alleles (5) while four alleles were found in locus PE18. Both were dinucleotide microsatellites with nine replicates. According to Weber (1990), the number of alleles per locus is related to the number of replicates in the microsatellite, which explains the polymorphism found in the locus PE66. The values of expected heterozygosity $(\mathrm{He})$ ranged from 0.33 (PE37) to 0.69 (PE08), with a mean of 0.57 (Table 5). These values reveal the wide genetic variability found in the genus Passiflora. Similar values were found by Cerqueira-Silva et al. (2012), who evaluated accessions of $P$. cincinnata and obtained $\mathrm{He}=0.51$, and Pádua et al. (2005), who obtained $\mathrm{He}=0.52$, using accessions of $P$. alata. Observed heterozygosity (Ho) ranged from 0.00 (PE37) to 0.981 (PE66), with mean of 0.52. Six of the loci analyzed presented heterozygosity higher than expected. Oliveira et al. (2005) evaluated accessions of P. edulis and found similar results for Ho, which ranged from 0.0 to 1.0. Cazé et al. (2012) used seven microsatellite loci to study the genetic structure of $P$. contracta and obtained Ho $=0.50$.

It is important to highlight that high values of Ho are expected in studies involving the genus Passiflora, since most species of this genus have the self-incompatibility system and are predominantly alogamous, with a large amount of heterozygous loci. However, Reis et al. (2011) 
Table 5. Characterization of 12 microsatellite loci used in the molecular characterization of species of Passiflora.

\begin{tabular}{lcccccc}
\hline Locus & TA $\left({ }^{\circ} \mathrm{C}\right)$ & $\mathrm{A}$ & $\begin{array}{c}\text { Number } \\
\text { of alleles }\end{array}$ & $\mathrm{He}$ & Ho & PIC \\
\hline PE13 & 60 & 0.4909 & 3.00 & 0.6094 & 0.3091 & 0.5313 \\
PE18 & 60 & 0.5943 & 4.00 & 0.5829 & 0.6415 & 0.5359 \\
PE74 & 58 & 0.5096 & 3.00 & 0.5497 & 0.9808 & 0.4495 \\
PE38 & 58 & 0.7245 & 2.00 & 0.3992 & 0.0612 & 0.3195 \\
PE37 & 60 & 0.7857 & 2.00 & 0.3367 & 0.0000 & 0.2800 \\
PE41 & 60 & 0.5192 & 4.00 & 0.5627 & 0.9423 & 0.4707 \\
PE66 & 60 & 0.3889 & 5.00 & 0.6799 & 0.9815 & 0.6213 \\
PE90 & 60 & 0.5568 & 4.00 & 0.6010 & 0.7273 & 0.5429 \\
A07FP1 & 54 & 0.6000 & 3.00 & 0.5588 & 0.4500 & 0.5071 \\
A08FP1 & 54 & 0.4615 & 3.00 & 0.6354 & 0.7115 & 0.5612 \\
PE08 & 56 & 0.4022 & 4.00 & 0.6999 & 0.1522 & 0.6453 \\
PE20 & 56 & 0.4688 & 4.00 & 0.6274 & 0.2917 & 0.5567 \\
Average & & 0.5419 & 3.42 & 0.5702 & 0.5208 & 0.5010
\end{tabular}

A: Frequency of the allele with greater frequency, He: expected heterozygosity, Ho: observed heterozygosity, PIC: polymorphic information content.

found low heterozygosity values $(\mathrm{He}=0.20$ and $\mathrm{Ho}=$ 0.15 ) while studying populations of passion fruit from two cycles of recurrent selection. The authors suggest that low molecular variability in this case can be attributed to the loss and fixation of alleles by the selection of agronomically favorable genotypes.

The polymorphic information content (PIC) calculated to estimate how much each primer was informative among the accessions studied ranged from 0.28 (PE 37) to 0.64 (PE08). Botstein et al. (1980) considered a marker highly informative when it presented PIC above 0.5 , reasonably informative when its values ranged between 0.25 and 0.50 , and mildly informative when values were below 0.24. According to this classification, PE08 and PE66 were considered highly informative, with PIC values of 0.64 and 0.62, respectively, while loci PE37 (0.28) and PE38 (0.31), which presented lower PIC values, were reasonably informative. The lower PIC values observed for these two loci can be attributed to the concentration of gene frequencies, which leads to deviation from the condition of maximum information content of a locus. This occurs when all alleles have similar frequencies.

Regarding the locus PE37, 78.6\% of the allele frequencies were concentrated in only one of the alleles. The same occurred in locus PE38, in which $72.4 \%$ of the allelic frequency was concentrated in only one allele. Such frequencies explain the lower PIC values and indicate that, in the present work, these loci generate the lowest content of information on the accessions analyzed. The first two main coordinates explained $70 \%$ of the variability between the groups (Figure 1). This value indicates that a two-dimensional graphical representation is appropriate to display the relationships among the species studied.

The graphical analysis of the main coordinates revealed dissimilarity between species belonging to the subgenus Decaloba ( $P$. suberosa L. and P. micropetala) and those allocated in the subgenus Passiflora. Wide genetic variability was found within the subgenus Passiflora and molecular similarity was verified among $P$. edulis, $P$. setacea DC., $P$. cincinnata, $P$. gibertii N.E. Br., and $P$. mucronata Lam. The work of Muschner et

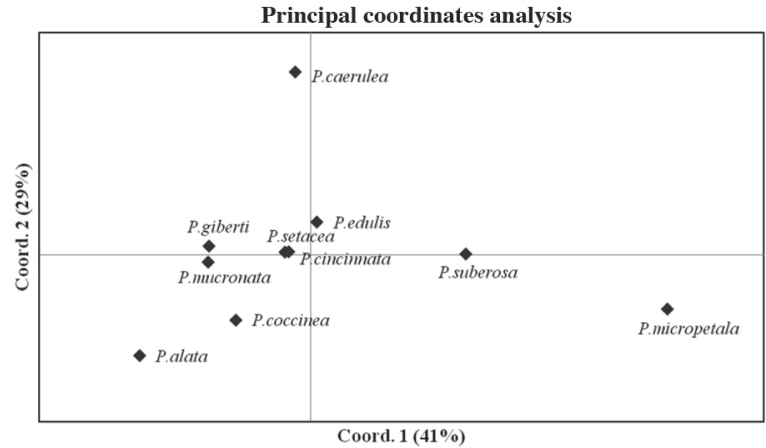

Figure 1. Genetic distance between species of the genus Passiflora obtained by the Principal Coordinates Analysis.

al. (2003) used preserved sequences of plastid DNA in order to know the phylogenetic relationships of this genus and corroborated the closeness among these species. The genetic distance between accessions ranged from 0.05 to 0.8 , which indicates significant diversity among the accessions analyzed. The smallest distance was observed between ALA235p1 and ALA235p3 (0.05), which belong to the species $P$. alata. The greatest dissimilarity was observed between the species $P$. suberosa and $P$. edulis (0.80). The high divergence between the species $P$. edulis and $P$. suberosa was also found in studies of Crochemore et al. (2003).

The dendrogram favored the formation of three major groups (Figure 2). Group I allocated the species $P$. suberosa and $P$. micropetala, group II consisted of accessions of $P$. setacea and $P$. edulis, and group III gathered $P$. cincinnata, $P$. caerulea L., accessions of $P$. setacea, $P$. alata, $P$. coccinea Aubl., $P$. gibertii, and $P$. mucronata. The grouping provided clear distinction between the subgenuses Decaloba and Passiflora. The latter is subdivided into two groups. The subgenus

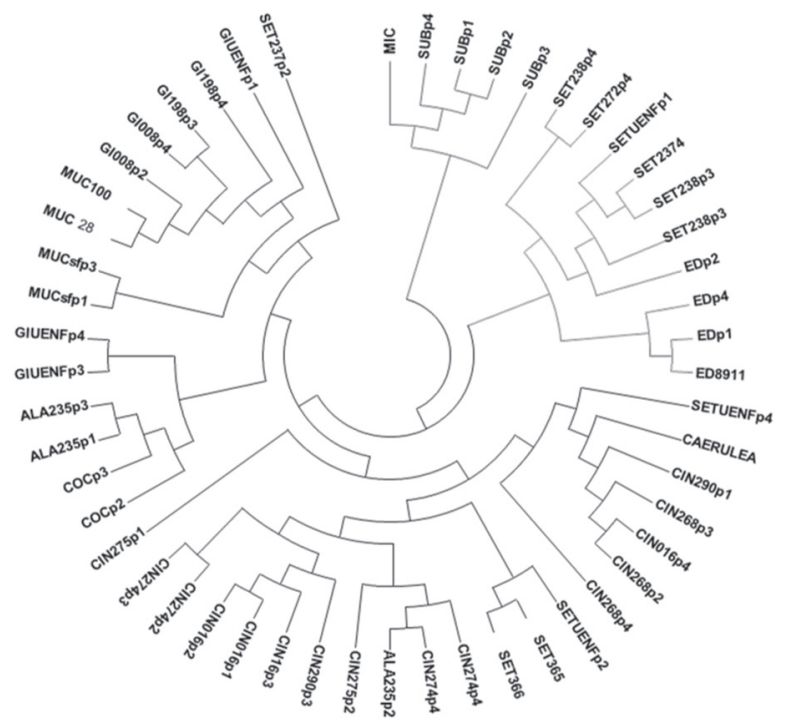

Figure 2. Dendrogram obtained by cluster analysis, using the shared allele genetic distance between accessions of 10 species of Passiflora and UPGMA clustering method. 
Decaloba had diversified prior to the subgenus Passiflora (Muschner et al., 2012). It explains the high molecular dissimilarity between Passiflora and Decaloba, thus accumulating molecular and morphological differences, including in modes of reproduction, flower size and number of chromosomes. The closeness among the species of the subgenus Passiflora is explained by its recent diversification (Muschner et al., 2012). Group II showed closeness between the two species, which indicates the potential use of interspecific crosses. Cerqueira-Silva et al. (2009) quantified the genetic diversity between P. edulis and $P$. setacea through physicochemical descriptors of the fruit. These authors observed that the variability between these species can be exploited by means of interspecific crosses aiming to increase the content of soluble solids and pulp production. Furthermore, these crosses may generate hybrids bearing genes resistant to Cowpea aphidborne mosaic potyvirus (CABMV), to which P. setacea is resistant (Fonseca et al., 2009).

Similarity among the species allocated in group III was also observed in a study conducted by Muschner et al. (2003), who used preserved sequences to perform the first study on molecular phylogeny of the genus. The sharing of alleles among these species and the use of loci in preserved regions may have contributed to this grouping. Passiflora setacea can be found in groups II and III, which reveals intraspecific variability in this species. This study showed the proximity between $P$. setacea and $P$. edulis of $P$. cincinnata was also found in a study on the phylogeny of the genus Passiflora (Muschner et al., 2003). Several studies have used molecular markers to assess the genetic variability among Passiflora species. Crochemore et al. (2003) used RAPD markers and found a clear separation and a significant diversity among the 11 species. Viana et al. (2010) used both RAPD and morphological markers to quantify the variability among six species of this genus. However, no relationship was observed among the species. Santos et al. (2011) found enormous genetic variability while using ISSR markers to access the variability of $P$. edulis from different sources.

The wide diversity observed is a trait of the genus Passiflora resulting from factors such as cross-pollination and self-incompatibility system. Knowledge of genetic diversity is fundamental for the conservation and maintenance of genetic resources in breeding programs (Costa et al., 2012) and helps understanding kinship between genotypes and identifying the best parents to obtain higher genetic gains in segregating populations (Viana et al., 2003; Ganga et al., 2004).

\section{CONCLUSIONS}

Heterologous primers amplified in most species analyzed, which enabled them to be used in many molecular studies on Passiflora. These markers allowed the estimation of the genetic distance between species and the clear discrimination of the subgenuses Decaloba and Passiflora. Wide genetic diversity was found among the species studied, which demonstrates potential to be used in plant breeding programs, since the interspecific crosses can be explored aiming to transfer favorable alleles.

\section{ACKNOWLEDGEMENTS}

The authors are grateful to FAPERJ and CNPq for funding the project and to Capes, for the scholarship granting.

\section{LITERATURE CITED}

Asif, M., J.I. Mirza, and Y. Zafar. 2008. High resolution metaphor agarose gel electrophoresis for genotyping with microsatellite markers. Pakistan Journal of Agricultural Sciences 45:75-79.

Bernacci, L.C., A.C. Cervi, M.A. Milward-de-Azevedo, T.S. Nunes, e A.C. Mezzonato. 2013. Passifloraceae. In Lista de espécies da flora do Brasil. Jardim Botânico do Rio de Janeiro. Available at http://floradobrasil.jbrj.gov.br/jabot/floradobrasil/FB128567 (accessed March 2014).

Botstein, D., R.L. White, M. Skolnick, and R.W. Davis. 1980. Construction of a genetic linkage map in man using restriction fragment length polymorphisms. American Journal of Human Genetics 32:314-331.

Cazé, A.L.R., R.A. Kriedt, L.B. Beheregaray, S.L. Bonatto, and L.B. Freitas. 2012. Isolation and characterization of microsatellite markers for Passiflora contracta. International Journal of Molecular Sciences 13:11343-11348.

Cerqueira-Silva, C.B.M., C.B. Cardoso-Silva, J.V.A. Nonato, R.X. Corrêa, and A.C. Oliveira. 2009. Genetic dissimilarity of "yellow" and "sleep" passion fruit accessions based on the fruits physical-chemical characteristics. Crop Breeding and Applied Biotechnology 9:210-218.

Cerqueira-Silva, C.B.M., E.S.L. Santos, A.M. Souza, G.M. Mori, E.J. Oliveira, R.X. Corrêa, et al. 2012. Development and characterization of microsatellite markers for the wild South American Passiflora cincinnata (Passifloraceae). American Journal of Botany 99:170-172.

Costa, J.L., O.N. Jesus, G. Alvarenga, F. Oliveira, and E.J. Oliveira. 2012. Effect of selection on genetic variability in yellow passion fruit. Crop Breeding and Applied Biotechnology 12:253-260.

Crochemore, M.L., H.B.C. Molinari, and L.G.E. Vieira. 2003. Genetic diversity in passion fruit (Passiflora spp.) evaluated by RAPD markers. Brazilian Archives of Biology and Technology 46:521-527.

Doyle, J.J., and J.L. Doyle. 1990. Isolation of plant DNA from fresh tissue. Focus 12:13-15.

Fonseca, K.G., F.G. Faleiro, J.R. Peixoto, N.T.V. Junqueira, M.S. Silva, G. Bellon, et al. 2009. Análise da recuperação do genitor recorrente em maracujazeiro-azedo por meio de marcadores RAPD. Revista Brasileira de Fruticultura 31:145-153.

Ganga, R.M.D., C. Ruggiero, E.G.M. Lemos, G.V.G. Grili, M.M. Gonçalves, E.A. Chagas, et al. 2004. Diversidade genética em maracujazeiro-amarelo utilizando marcadores moleculares AFLP. Revista Brasileira de Fruticultura 26:494-498.

Junqueira, N.T.V., D.A.C. Lage, M.D. Braga, J.R. Peixoto, T.A. Borges, e S.R.M. Andrade. 2006. Reação a doenças e produtividade de um clone de maracujazeiro-azedo propagado por estaquia e enxertia em estacas herbáceas de passiflora silvestre. Revista Brasileira de Fruticultura 28:97-100.

Liu, K., and S.V. Muse. 2005. PowerMarker: an integrated analysis environment for genetic marker analysis. Bioinformatics 21:21282129.

Meletti, L.M.M. 2011. Avanços na cultura do maracujá no Brasil. Revista Brasileira de Fruticultura 45:83-91. 
Muschner, R.I.A.C., A.L.P. Lorenz, A.R.C. Cervi, S.A.L. Bonatto, T.T. Souza-Chies, F.R.M. Salzano, et al. 2003. First molecular phylogenetic analysis of passiflora (Passifloraceae). American Journal of Botany 90:1229-1238.

Muschner, V.C., P.M. Zamberlan, S.L. Bonatto, and L.B. Freitas. 2012. Phylogeny, biogeography and divergence times in Passiflora (Passifloraceae). Genetics and Molecular Biology 35:1036-1043.

Oliveira, E.J. 2006. Desenvolvimento e uso de marcadores microssatélites para construção e integração de mapas genéticos de maracujá-amarelo (Passiflora edulis Sims f. flavicarpa Deg.) 152 p. Tese (Doutorado). Escola Superior de Agricultura Luiz de Queiroz, Piracicaba, São Paulo, Brasil.

Oliveira, E.J., J.G. Pádua, M.I. Zucchi, L.E.A. Camargo, M.H.P. Fungaro, M.L.C. Vieira. 2005. Development and characterization of microsatellite markers from the yellow passion fruit (Passiflora edulis f. flavicarpa). Molecular Ecology Notes 5:331-333.

Pádua, J.G., E.J. Oliveira, M.I. Zucchi, G.C.X. Oliveira, L.E.A. Camargo, and M.L.C. Vieira. 2005. Isolation and characterization of microsatellite markers from the sweet passion fruit (Passiflora alata Curtis: Passifloraceae). Molecular Ecology Notes 5:863865.

Pérez, J.O., G.C. D'eeckenbrugge, M. Restepo, A. Jarvis, M. Salazar, and C. Caetano. 2007. Diversity of Colombian Passifloraceae biogeography and an updated list for conservation. Biota Colombiana 8:1-45.

Reis, R.V., E.J. Oliveira, A.P. Viana, T.N.S. Pereira, M.G. Pereira, e M.G.M. Silva. 2011. Diversidade genética em seleção recorrente de maracujazeiro-amarelo detectada por marcadores microssatélites. Pesquisa Agropecuaria Brasileira 46:51-57.
Santos, L.F., E.J. Oliveira, A.S. Silva, F.M. Carvalho, J.L. Costa, and J.G. Pádua. 2011. ISSR markers as a tool for the assessment of genetic diversity in Passiflora. Biochemical Genetics 49:540-554.

Schlötterer, C. 2004. The evolution of molecular markers - just a matter of fashion? Nature Reviews Genetics 5:63-69.

Varshney, R.K., A. Graner, and M.E. Sorrells. 2005. Genic microsatellite markers in plants: features and applications. Trends in Biotechnology 23:48-55.

Viana, A.P., T.N.S. Pereira, M.G. Pereira, M.M. de Souza, J.F.M. Maldonado, and A.T. do Amaral Jr. 2003. Genetic diversity among yellow passion fruit commercial genotypes and among Passiflora species using RAPD. Revista Brasileira de Fruticultura 25:489493.

Viana, A.J.C., M.M. Souza, I.S. Araújo, and R.X. Corrêa. 2010. Genetic diversity in Passiflora species determined by morphological and molecular characteristics. Biologia Plantarum 54:535-538.

Vicente, M.C., F.A. Guzmán, J. Engels, and R.V. Ramanatha. 2005. Genetic characterization and its use in decision making for the conservation of crop germplasm. p. 121-128. In The role of biotechnology for the characterisation and conservation of crop, forestry, animal and fishery genetic resources, Turin, Italy. 5-7 March. FAO, Rome, Italy. 